\title{
Dietary fiber in irritable bowel syndrome (Review)
}

\author{
MAGDY EL-SALHY ${ }^{1-3}$, SYNNE OTTERASEN YSTAD $^{3}$, TAREK MAZZAWI ${ }^{2,3}$ and DORIS GUNDERSEN ${ }^{4}$ \\ ${ }^{1}$ Division of Gastroenterology, Department of Medicine, Stord Hospital, 5416 Stord; ${ }^{2}$ Department of Clinical Medicine, \\ University of Bergen; ${ }^{3}$ National Centre for Functional Gastrointestinal Disorders, Department of Medicine, \\ Haukeland University Hospital, 5020 Bergen; ${ }^{4}$ Department of Research and Innovation, \\ Helse-Fonna, 5528 Haugesund, Norway
}

Received March 12, 2017; Accepted June 9, 2017

DOI: $10.3892 /$ ijmm.2017.3072

\begin{abstract}
Irritable bowel syndrome (IBS) is a common chronic gastrointestinal disorder. It is widely believed that IBS is caused by a deficient intake of dietary fiber, and most physicians recommend that patients with IBS increase their intake of dietary fiber in order to relieve their symptoms. However, different types of dietary fiber exhibit marked differences in physical and chemical properties, and the associated health benefits are specific for each fiber type. Short-chain soluble and highly fermentable dietary fiber, such as oligosaccharides results in rapid gas production that can cause abdominal pain/discomfort, abdominal bloating/distension and flatulence in patients with IBS. By contrast, long-chain, intermediate viscous, soluble and moderately fermentable dietary fiber, such as psyllium results in a low gas production and the absence of the symptoms related to excessive gas production. The effects of type of fiber have been documented in the management of IBS, and it is known to improve the overall symptoms in patients with IBS. Dietary fiber acts on the gastrointestinal tract through several mechanisms, including increased fecal mass with mechanical stimulation/irritation of the colonic mucosa with increasing secretion and peristalsis, and the actions of fermentation byproducts, particularly short-chain fatty acids, on the intestinal microbiota, immune system and the neuroendocrine system of the gastrointestinal tract. Fiber supplementation, particularly psyllium, is both safe and effective in improving IBS symptoms globally. Dietary fiber also has other health benefits, such as lowering blood cholesterol levels, improving glycemic control and body weight management.
\end{abstract}

Correspondence to: Professor Magdy El-Salhy, Division of Gastroenterology, Department of Medicine, Stord Hospital, Box 4000, 5416 Stord, Norway

E-mail: magdy.el-salhy@helse-fonna.no

Key words: microbiota, enteric nervous system, fermentation, immune system, intestinal endocrine cells, laxation, meteorism, psyllium

\section{Contents}

1. Introduction

2. Types and characteristics of dietary fiber

3. Mechanisms of action of dietary fiber in IBS

4. Fiber supplementation in the treatment of IBS

5. Conclusion

\section{Introduction}

Irritable bowel syndrome (IBS) is a chronic common gastrointestinal disorder with a prevalence of $10-20 \%$ among the adult population worldwide (1-15). The diagnosis of IBS is based mainly on symptom assessment using the Rome criteria $(16,17)$. The cardinal symptom is abdominal discomfort/pain, which is associated with altered bowel habits and abdominal bloating/distension $(1,4)$. Patients with IBS are divided into four subtypes according to the stool pattern: diarrhea-predominant IBS (IBS-D), constipation-predominant IBS (IBS-C), mixeddiarrhea-and-constipation IBS (IBS-M) and unclassified IBS $(16,17)$. Patients with IBS are usually diagnosed at a young age, and IBS is more common in women than in men (3-6,8,9,11, $12,14,15,18,19)$. Although IBS is not associated with increased mortality, it considerably reduces the quality of life $(1,19-21)$ and is an economic burden to society (22).

Dietary fiber includes non-digestible carbohydrates and the complex polymer, lignin, which are present in plants and have physiological effects in humans (23). Dietary fiber has long been used in the treatment of several gastrointestinal conditions (24-38). It is widely believed that IBS is caused primarily by a deficient intake of dietary fiber (39). Increasing the dietary fiber intake has been the standard recommendation for patients with IBS (1). However, a systematic meta-analysis based on 12 small studies showed that increased dietary fiber consumption by patients with IBS did not improve IBS symptoms compared to placebo or a low-fiber diet (39). Other studies have shown that while consuming water-insoluble fiber does not improve IBS symptoms, consuming soluble fiber improves overall IBS symptoms $(40,41)$. Subsequent studies have shone new light on fiber supplementation as a treatment for IBS. Several comprehensive reviews have been published recently on the role of dietary fibers in IBS (42-46). The present review aimed to discuss the efficacy of 
fiber supplementation in the treatment of IBS, the type of dietary fiber that should be recommended, and the mechanisms underlying the effects of dietary fiber, particularly those concerning the interaction between fibers, microbiota, the immune system and the neuroendocrine regulatory system of the gut.

\section{Types and characteristics of dietary fiber}

Different types of dietary fiber are characterized by marked differences in physical and chemical structure, with the health benefits of dietary fiber being specific to each fiber type (23). Dietary fiber can be divided into soluble types (i.e., dissolving in water) and insoluble types based on their physical and chemical properties $(47,48)$. Soluble dietary fiber can be subdivided into viscous (gel forming) and non-viscous $(23,47)$. Dietary fiber can be divided further into short-chain and long-chain carbohydrates, and fermentable or non-fermentable types (49-53). Fermentable oligosaccharides, disaccharides, monosaccharides and polyols (FODMAPs) are closely associated with the focus of this review, and are to be considered to be the short-chain carbohydrate, soluble, and highly fermentable type of dietary fiber.

Short-chain, soluble and highly fermentable dietary fiber (e.g., oligosaccharides) results in rapid gas production that can outpace the capacity of the gastrointestinal tract to absorb gas into the bloodstream for final elimination through the lungs. This imbalance can cause abdominal pain/discomfort, abdominal bloating/distension and flatulence $(23,51,54)$. On the other hand, long-chain, intermediate viscous, soluble and moderately fermentable dietary fiber (e.g., psyllium) results in a low gas production and the absence of the symptoms related to excessive gas production $(23,54,55)$.

\section{Mechanisms of action of dietary fiber in IBS}

Laxative effects. Insoluble dietary fiber increases fecal mass and accelerates colonic transit via mechanical stimulation/irritation of the colonic mucosa with increasing secretion and peristalsis $(23,56-63)$. Soluble dietary fiber is fermented by bacteria in the large intestine, which increases the stool bulk by increasing the biomass by fermentation byproducts, such as gas and short-chain fatty acids $(61,62)$. The oro-anal transit time and sensation are affected by these changes and probably also through other effects on microbiota, immune cells, intestinal endocrine cell, enteric nervous system and permeability (64-75) (Fig. 1). Soluble viscous dietary fiber (e.g., psyllium) is minimally fermented and forms a gel that is preserved during its passage through the large bowel and normalizes the stool form (26,76-79).

Interaction of dietary fiber with microbiota and the immune system. There is an increasing body of evidence to indicate that dietary fiber acts as a prebiotic that influences the composition of the intestinal microbiota (80-88) (Fig. 1). Furthermore, the fermentation of dietary fiber byproducts, such as short-chain fatty acids (acetate, propionate and butyrate) and the decrease in luminal colonic $\mathrm{pH}$ promote the growth of beneficial bacteria, such as lactobacilli and bifidobacteria (80-88).

Butyrate is one of the short-chain fatty acids that are produced by the fermentation of dietary fiber $(23,54)$. Butyrate has been recently reported to suppress colonic inflam- mation in two ways: i) by inducing T-cell apoptosis, thus eliminating the source of inflammation, and ii) by suppressing interferon- $\gamma$ (IFN- $\gamma)$-mediated inflammation (Fig. 1) (89-91).

Interaction between dietary fiber and the neuroendocrine system (NES) of the gastrointestinal tract. The NES of the gastrointestinal tract comprises gastrointestinal endocrine cells and the enteric nervous system (Fig. 1). Various different types of endocrine cells are scattered between the epithelial cells of the mucosa $(1,92-97)$. These endocrine cells constitute approximately $1 \%$ of all epithelial cells in the gastrointestinal tract $(92,93,98-100)$ and they have specialized sensors in the form of microvilli that project into the lumen and respond to luminal stimuli by releasing hormones (101-113). The distribution, functions and modes of action of the most important gastrointestinal endocrine cells have been described in detail elsewhere $(95,114,115)$. Briefly, each cell type secretes one or more signaling substances into the lamina propria, where these substances act directly on nearby structures (autocrine/paracrine mode), indirectly via an endocrine mode of action (by circulating in the blood to reach distant targets), and/or through a synaptic mode of action (116). The enteric nervous system comprises two plexi: the submucosal plexus and myenteric plexus. The NES regulates several functions of the gastrointestinal tract, including sensation, motility, secretion, absorption, local immune defense and food intake $(22,92,93,95,117)$. The components of the NES interact and integrate with each other, the autonomic nervous system, and the afferent and efferent nerve fibers of the central nervous system $(22,95,117,118)$.

Dietary fiber appears to improve the global symptoms in patients with IBS, abdominal discomfort/pain, abdominal bloating/distension and altered bowel habit, probably by affecting the NES. Changes in the luminal intestinal $\mathrm{pH}$ and pressure can stimulate the release of the hormone serotonin, which is known to play a pivotal role in visceral sensitivity (95). The short-chain fatty acids produced by the fermentation of dietary fiber appear to affect several intestinal hormones, such as peptide YY (PYY) and glucagon-like peptide-1 (119-122). PYY is known to stimulate the absorption of water and electrolytes, and regulate the 'ileal brake' (123-128). Furthermore, PYY inhibits prostaglandin $\mathrm{E} 2$ and vasoactive intestinal polypeptide, which stimulate intestinal fluid secretion (129-131). This can explain the effect of dietary fiber on gastrointestinal transit and secretion. It has recently been reported that changing from a typical Norwegian diet to a FODMAP-reduced diet is accompanied by changes in densities of the gastrointestinal endocrine cells in patients with IBS (132-138). Since FODMAPs by definition constitute dietary fiber, these observations show that changing the dietary fiber intake is associated with changes in the gastrointestinal endocrine cells.

Short-chain fatty acids, particularly butyrate, produced by the fermentation of dietary fiber have been found to affect neurons of the enteric nervous system $(119,139)$. Whether this is a direct effect on the enteric nervous system or involves indirect effects on the gastrointestinal endocrine cells remains to be determined.

\section{Fiber supplementation in the treatment of IBS}

Physicians (particularly those in the primary care system) usually recommend patients with IBS to increase their intake 


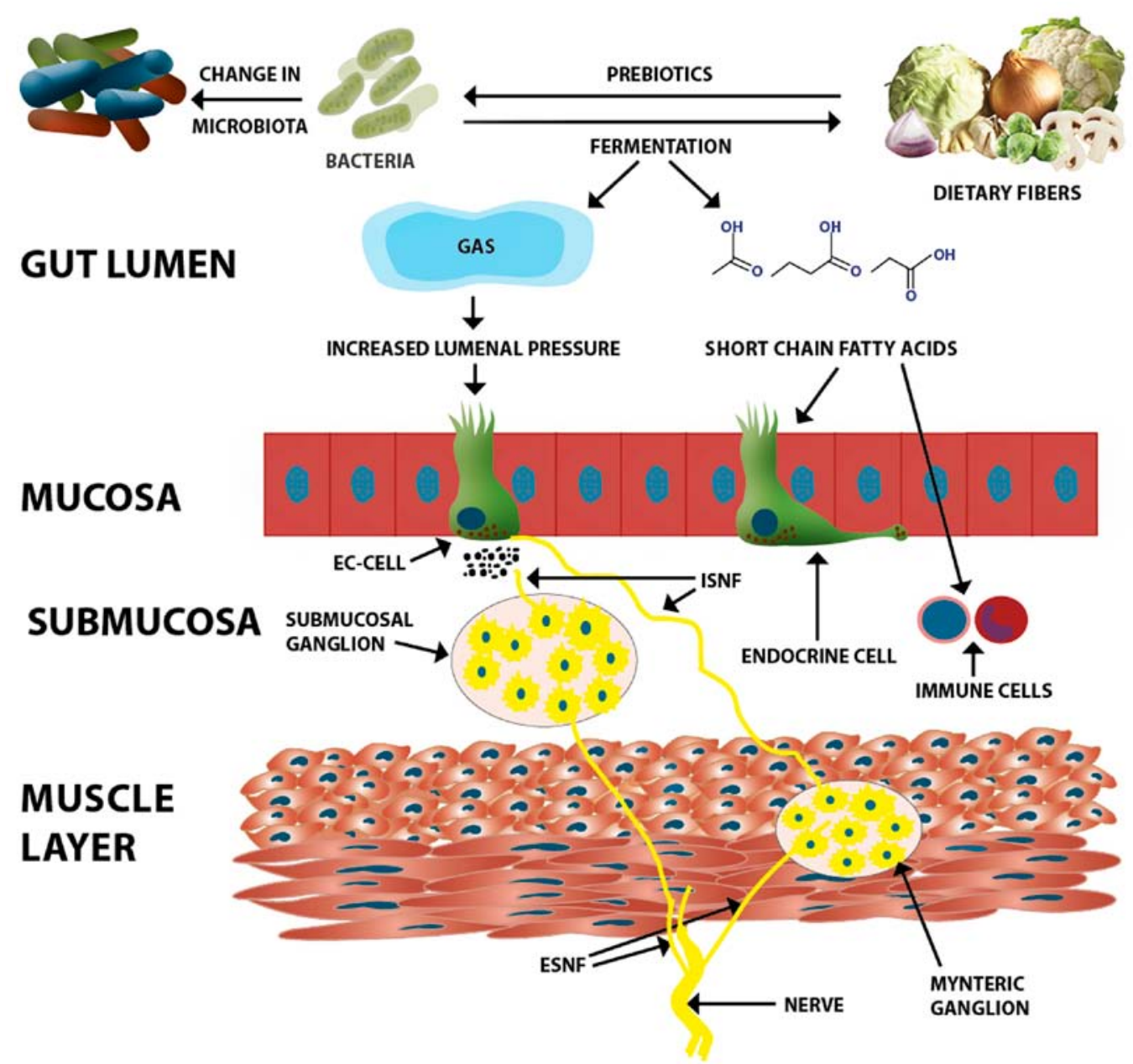

Figure 1. Likely mechanisms through which dietary fiber affects the functions of the gastrointestinal tract. Dietary fiber acts as a prebiotic to intestinal microbiota that causes changes in their composition and induces the growth of beneficial bacteria. The intestinal microbiota in turn causes the fermentation of the dietary fiber, producing gas, short-chain fatty acids, and other byproducts. The gas production increases the fecal mass and increases the luminal pressure. These mechanisms together with lowering of the luminal $\mathrm{pH}$ stimulate the secretion of serotonin from the EC-cell. Serotonin plays an important role in visceral sensitivity. Short-chain fatty acids act on intestinal endocrine cells and/or the neurons of the enteric nervous system to change gastrointestinal motility and secretion. Short-chain fatty acids act also on immune cells and thereby reduce inflammation. EC-cell, enterochromaffin cell; ISNF, intrinsic sensory nerve fibers; ESNF, extrinsic sensory nerve fibers.

of dietary fiber to $20-35 \mathrm{~g}$ daily in order to regulate the stools and reduce abdominal pain and meteorism (140-143). Supplementation with long-chain, intermediate viscous, soluble and moderately fermentable dietary fiber such as psyllium improves the global symptoms of IBS (26,144-147). A recent meta-analysis that evaluated dietary fiber supplementation in 14 randomized controlled trials involving 906 patients with IBS found that fiber supplementation (especially with psyllium) was effective in improving global IBS symptoms compared to placebo (46).

Dietary fiber supplementation seems to be safe $(46,147)$, although transient abdominal bloating/distention can occur if it is introduced too rapidly $(23,148)$. Recommending fiber supplementation to patients with IBS is also inexpensive while having documented effects on IBS symptoms and other health benefits $(23,147,149)$.

\section{Conclusion}

Dietary fiber affects the bowel habits through increasing the stool bulk with mechanical stimulation of the colonic mucosa.
The fermentation of dietary fiber by intestinal microbiota lowers the luminal $\mathrm{pH}$ and has several byproducts, such as gas and short-chain fatty acids. The gas increases the luminal pressure while short-chain fatty acids, particularly butyrate, affect the NES and consequently affect gastrointestinal secretion and motility. Dietary fiber has additional health benefits such as lowering the blood cholesterol level, improving glycemic control, and body weight management $(23,54,55)$.

The different types of dietary fiber exhibit marked differences in physical and chemical properties, and not all types of fiber are beneficial for patients with IBS. A general recommendation to increase fiber intake in this group of patients would be inappropriate since it could worsen the symptoms (39). Long-chain, intermediate viscous, soluble, and moderately fermentable dietary fiber (e.g.,psyllium) has documented affects in the management of IBS, and can improve the overall symptoms of patients with IBS $(23,41,46,51,54)$. Supplementation with this type of dietary fiber should be recommended to patients with all of the IBS subtypes, namely IBS-D, IBS-M, and IBS-C. When beginning a fiber supplementation regimen, a transient period of abdominal bloating/distension, discom- 
fort, and change in the bowel habits may occur (150). Fiber supplementation should therefore be started gradually, with the intake increased by no more than $5 \mathrm{~g} / \mathrm{day}$ each week (23).

\section{Acknowledgements}

The studies conducted by the authors and cited in this review were supported by grants from Helse-Vest, Norway (grant no. 911978), and Helse-Fonna Norway (grant no. 40415).

\section{References}

1. El-Salhy M, Gundersen D, Hatlebakk JG and Hausken T: Irritable Bowel Syndrome: Diagnosis, Pathogenesis and Treatment Options. Nova Science Publishers, Inc., New York, NY, 2012.

2. Thompson WG: A world view of IBS. In: Irritable bowel syndrome. Camilleri M and Spiller RC (eds). Saunders, Philadelphia and London, pp17-26, 2002.

3. Agréus L, Svärdsudd K, Nyrén O and Tibblin G: Irritable bowel syndrome and dyspepsia in the general population: Overlap and lack of stability over time. Gastroenterology 109: 671-680, 1995.

4. Thompson WG, Irvine EJ, Pare P, Ferrazzi S and Rance L: Functional gastrointestinal disorders in Canada: First population-based survey using Rome II criteria with suggestions for improving the questionnaire. Dig Dis Sci 47: 225-235, 2002.

5. Kennedy TM, Jones RH, Hungin AP, O'flanagan H and Kelly P: Irritable bowel syndrome, gastro-oesophageal reflux, and bronchial hyper-responsiveness in the general population. Gut 43: 770-774, 1998.

6. Drossman DA, Li Z, Andruzzi E, Temple RD, Talley NJ Thompson WG, Whitehead WE, Janssens J, Funch-Jensen P, Corazziari E, et al: U.S. householder survey of functional gastrointestinal disorders. Prevalence, sociodemography, and health impact. Dig Dis Sci 38: 1569-1580, 1993.

7. Talley NJ, Gabriel SE, Harmsen WS, Zinsmeister AR and Evans RW: Medical costs in community subjects with irritable bowel syndrome. Gastroenterology 109: 1736-1741, 1995.

8. Hungin AP, Whorwell PJ, Tack J and Mearin F: The prevalence, patterns and impact of irritable bowel syndrome: An international survey of 40,000 subjects. Aliment Pharmacol Ther 17: 643-650, 2003.

9. Jones R and Lydeard S: Irritable bowel syndrome in the general population. BMJ 304: 87-90, 1992.

10. Bordie AK: Functional disorders of the colon. J Indian Med Assoc 58: 451-456, 1972.

11. O'Keefe EA, Talley NJ, Zinsmeister AR and Jacobsen SJ: Bowel disorders impair functional status and quality of life in the elderly: A population-based study. J Gerontol A Biol Sci Med Sci 50: M184-M189, 1995.

12. Everhart JE and Renault PF: Irritable bowel syndrome in officebased practice in the United States. Gastroenterology 100: 998-1005, 1991.

13. Wilson S, Roberts L, Roalfe A, Bridge P and Singh S: Prevalence of irritable bowel syndrome: A community survey. Br J Gen Pract 54: 495-502, 2004.

14. Quigley EM, Locke GR, Mueller-Lissner S, Paulo LG, Tytgat GN, Helfrich I and Schaefer E: Prevalence and management of abdominal cramping and pain: A multinational survey. Aliment Pharmacol Ther 24: 411-419, 2006.

15. Harvey RF, Salih SY and Read AE: Organic and functional disorders in 2000 gastroenterology outpatients. Lancet 1: 632-634, 1983.

16. Spiller R, Aziz Q, Creed F, Emmanuel A, Houghton L, Hungin P, Jones R, Kumar D, Rubin G, Trudgill N, et al; Clinical Services Committee of The British Society of Gastroenterology: Guidelines on the irritable bowel syndrome: Mechanisms and practical management. Gut 56: 1770-1798, 2007.

17. Longstreth GF, Thompson WG, Chey WD, Houghton LA, Mearin F and Spiller RC: Functional bowel disorders. Gastroenterology 130: 1480-1491, 2006.

18. Thompson WG and Heaton KW: Functional bowel disorders in apparently healthy people. Gastroenterology 79: 283-288, 1980.

19. Miller V, Whitaker K, Morris JA and Whorwell PJ: Gender and irritable bowel syndrome: The male connection. J Clin Gastroenterol 38: 558-560, 2004.
20. Whitehead WE, Burnett CK, Cook EW III and Taub E: Impact of irritable bowel syndrome on quality of life. Dig Dis Sci 41: 2248-2253, 1996.

21. Gralnek IM, Hays RD, Kilbourne A, Naliboff B and Mayer EA: The impact of irritable bowel syndrome on health-related quality of life. Gastroenterology 119: 654-660, 2000.

22. El-Salhy M: Irritable bowel syndrome: Diagnosis and pathogenesis. World J Gastroenterol 18: 5151-5163, 2012.

23. Chutkan R, Fahey G, Wright WL and McRorie J: Viscous versus nonviscous soluble fiber supplements: Mechanisms and evidence for fiber-specific health benefits. J Am Acad Nurse Pract 24: 476-487, 2012.

24. Bouchoucha M, Faye A, Savarieau B and Arsac M: Effect of an oral bulking agent and a rectal laxative administered alone or in combination for the treatment of constipation. Gastroenterol Clin Biol 28: 438-443, 2004.

25. Ramkumar D and Rao SS: Efficacy and safety of traditional medical therapies for chronic constipation: Systematic review. Am J Gastroenterol 100: 936-971, 2005.

26. McRorie JW, Daggy BP, Morel JG, Diersing PS, Miner PB and Robinson M: Psyllium is superior to docusate sodium for treatment of chronic constipation. Aliment Pharmacol Ther 12: 491-497, 1998.

27. Mehmood MH, Aziz N, Ghayur MN and Gilani AH: Pharmacological basis for the medicinal use of psyllium husk (Ispaghula) in constipation and diarrhea. Dig Dis Sci 56: 1460-1471, 2011.

28. Washington N, Harris M, Mussellwhite A and Spiller RC: Moderation of lactulose-induced diarrhea by psyllium: Effects on motility and fermentation. Am J Clin Nutr 67: 317-321, 1998.

29. Wenzl HH, Fine KD, Schiller LR and Fordtran JS: Determinants of decreased fecal consistency in patients with diarrhea. Gastroenterology 108: 1729-1738, 1995.

30. Qvitzau S, Matzen P and Madsen P: Treatment of chronic diarrhoea: Loperamide versus ispaghula husk and calcium. Scand J Gastroenterol 23: 1237-1240, 1988.

31. Eherer AJ, Santa Ana CA, Porter J and Fordtran JS: Effect of psyllium, calcium polycarbophil, and wheat bran on secretory diarrhea induced by phenolphthalein. Gastroenterology 104: 1007-1012, 1993.

32. Murphy J, Stacey D, Crook J, Thompson B and Panetta D: Testing control of radiation-induced diarrhea with a psyllium bulking agent: a pilot study. Can Oncol Nurs J 10: 96-100, 2000.

33. Sherman DS and Fish DN: Management of protease inhibitorassociated diarrhea. Clin Infect Dis 30: 908-914, 2000.

34. Fernández-Bañares F, Hinojosa J, Sánchez-Lombraña JL, Navarro E, Martínez-Salmerón JF, García-Pugés A, GonzálezHuix F, Riera J, González-Lara V, Domínguez-Abascal F, et al; Spanish Group for the Study of Crohn's Disease and Ulcerative Colitis (GETECCU): Randomized clinical trial of Plantago ovata seeds (dietary fiber) as compared with mesalamine in maintaining remission in ulcerative colitis. Am J Gastroenterol 94: 427-433, 1999.

35. Fujimori S, Gudis K, Mitsui K, Seo T, Yonezawa M, Tanaka S, Tatsuguchi A and Sakamoto C: A randomized controlled trial on the efficacy of synbiotic versus probiotic or prebiotic treatment to improve the quality of life in patients with ulcerative colitis. Nutrition 25: 520-525, 2009.

36. Fujimori S, Tatsuguchi A, Gudis K, Kishida T, Mitsui K, Ehara A, Kobayashi T, Sekita Y, Seo T and Sakamoto C: High dose probiotic and prebiotic cotherapy for remission induction of active Crohn's disease. J Gastroenterol Hepatol 22: 1199-1204, 2007.

37. Smalley JR, Klish WJ, Campbell MA and Brown MR: Use of psyllium in the management of chronic nonspecific diarrhea of childhood. J Pediatr Gastroenterol Nutr 1: 361-363, 1982.

38. Heather DJ, Howell L, Montana M, Howell M and Hill R: Effect of a bulk-forming cathartic on diarrhea in tube-fed patients. Heart Lung 20: 409-413, 1991.

39. Ford AC, Talley NJ, Spiegel BM, Fox x-Orenstein AE, Schiller L, Quigley EM and Moayyedi P: Effect of fibre, antispasmodics, and peppermint oil in the treatment of irritable bowel syndrome: Systematic review and meta-analysis. BMJ 337: a2313, 2008.

40. Francis CY and Whorwell PJ: Bran and irritable bowel syndrome: Time for reappraisal. Lancet 344: 39-40, 1994.

41. Bijkerk CJ, de Wit NJ, Muris JW, Whorwell PJ, Knottnerus JA and Hoes AW: Soluble or insoluble fibre in irritable bowel syndrome in primary care? Randomised placebo controlled trial. BMJ 339: b3154, 2009. 
42. Philpott H, Nandurkar S, Lubel J and Gibson PR: Food, fibre, bile acids and the pelvic floor: An integrated low risk low cost approach to managing irritable bowel syndrome. World J Gastroenterol 21: 11379-11386, 2015.

43. Nagarajan N, Morden A, Bischof D, King EA, Kosztowski M, Wick EC and Stein EM: The role of fiber supplementation in the treatment of irritable bowel syndrome: A systematic review and meta-analysis. Eur J Gastroenterol Hepatol 27: 1002-1010, 2015.

44. Rao SS, Yu S and Fedewa A: Systematic review: Dietary fibre and FODMAP-restricted diet in the management of constipation and irritable bowel syndrome. Aliment Pharmacol Ther 41: $1256-1270,2015$

45. Ford AC, Moayyedi P, Lacy BE, Lembo AJ, Saito YA, Schiller LR, Soffer EE, Spiegel BM and Quigley EM; Task Force on the Management of Functional Bowel Disorders: American College of Gastroenterology monograph on the management of irritable bowel syndrome and chronic idiopathic constipation. Am J Gastroenterol 109 (Suppl 1): S2-26; quiz S27, 2014.

46. Moayyedi P, Quigley EM, Lacy BE, Lembo AJ, Saito YA, Schiller LR, Soffer EE, Spiegel BM and Ford AC: The effect of fiber supplementation on irritable bowel syndrome: A systematic review and meta-analysis. Am J Gastroenterol 109: 1367-1374, 2014.

47. Anderson JW, Baird P, Davis RH Jr, Ferreri S, Knudtson M, Koraym A, Waters V and Williams CL: Health benefits of dietary fiber. Nutr Rev 67: 188-205, 2009.

48. Dikeman CL and Fahey GC Jr: Viscosity as related to dietary fiber: A review. Crit Rev Food Sci Nutr 46: 649-663, 2006.

49. Heizer WD, Southern S and McGovern S: The role of diet in symptoms of irritable bowel syndrome in adults: A narrative review. J Am Diet Assoc 109: 1204-1214, 2009.

50. Chouinard LE: The role of psyllium fibre supplementation in treating irritable bowel syndrome. Can J Diet Pract Res 72 : e107-114, 2011.

51. Bijkerk CJ, Muris JW, Knottnerus JA, Hoes AW and de Wit NJ: Systematic review: The role of different types of fibre in the treatment of irritable bowel syndrome. Aliment Pharmacol Ther 19: 245-251, 2004.

52. Biesiekierski JR, Rosella O, Rose R, Liels K, Barrett JS Shepherd SJ, Gibson PR and Muir JG: Quantification of fructans, galacto-oligosacharides and other short-chain carbohydrates in processed grains and cereals. J Hum Nutr Diet 24: 154-176, 2011

53. Muir JG, Rose R, Rosella O, Liels K, Barrett JS, Shepherd SJ and Gibson PR: Measurement of short-chain carbohydrates in common Australian vegetables and fruits by high-performance liquid chromatography (HPLC). J Agric Food Chem 57: 554-565, 2009.

54. Eswaran S, Muir J and Chey WD: Fiber and functional gastrointestinal disorders. Am J Gastroenterol 108: 718-727, 2013.

55. McRorie J, Kesler J, Bishop L, Filloon T, Allgood G, Sutton M, Hunt T, Laurent A and Rudolph C: Effects of wheat bran and Olestra on objective measures of stool and subjective reports of GI symptoms. Am J Gastroenterol 95: 1244-1252, 2000.

56. Tomlin $\mathrm{J}$ and Read NW: Laxative properties of indigestible plastic particles. BMJ 297: 1175-1176, 1988.

57. Riottot M, Sacquet E and Leprince C: Effect of wheat bran upon gastro-intestinal transit in germ-free and conventional rats. Digestion 29: 37-41, 1984.

58. Burkitt DP, Walker AR and Painter NS: Effect of dietary fibre on stools and the transit-times, and its role in the causation of disease. Lancet 2: 1408-1412, 1972.

59. Lewis SJ and Heaton KW: Roughage revisited: The effect on intestinal function of inert plastic particles of different sizes and shape. Dig Dis Sci 44: 744-748, 1999.

60. Lewis SJ and Heaton KW: The intestinal effects of bran-like plastic particles: Is the concept of 'roughage' valid after all? Eur J Gastroenterol Hepatol 9: 553-557, 1997.

61. Stephen AM and Cummings JH: Mechanism of action of dietary fibre in the human colon. Nature 284: 283-284, 1980.

62. Stephen AM and Cummings JH: Water holding by dietary fibre in vitro and its relationship to faecal bulking in man. Proc Nutr Soc 38: 55A, 1979.

63. Cummings JH and Stephen AM: The role of dietary fibre in the human colon. Can Med Assoc J 123: 1109-1114, 1980.

64. Camilleri M: Management of the irritable bowel syndrome. Gastroenterology 120: 652-668, 2001.

65. Camilleri M and Katzka DA: Irritable bowel syndrome: Methods, mechanisms, and pathophysiology. Genetic epidemiology and pharmacogenetics in irritable bowel syndrome. Am J Physiol Gastrointest Liver Physiol 302: G1075-G1084, 2012.
66. Camilleri M, Heading RC and Thompson WG: Clinical perspectives, mechanisms, diagnosis and management of irritable bowel syndrome. Aliment Pharmacol Ther 16: 1407-1430, 2002.

67. Gonlachanvit S, Coleski R, Owyang C and Hasler W: Inhibitory actions of a high fibre diet on intestinal gas transit in healthy volunteers. Gut 53: 1577-1582, 2004.

68. Hamer HM, Jonkers D, Venema K, Vanhoutvin S, Troost FJ and Brummer RJ: Review article: The role of butyrate on colonic function. Aliment Pharmacol Ther 27: 104-119, 2008.

69. Hamer HM, Jonkers DM, Bast A, Vanhoutvin SA, Fischer MA, Kodde A, Troost FJ, Venema K and Brummer RJ: Butyrate modulates oxidative stress in the colonic mucosa of healthy humans. Clin Nutr 28: 88-93, 2009.

70. Hamer HM, Jonkers DM, Loof A, Vanhoutvin SA, Troost FJ, Venema K, Kodde A, Koek GH, Schipper RG, van Heerde WL, et al: Analyses of human colonic mucus obtained by an in vivo sampling technique. Dig Liver Dis 41: 559-564, 2009.

71. Hamer HM, Jonkers DM, Renes IB, Vanhoutvin SA, Kodde A, Troost FJ, Venema K and Brummer RJ: Butyrate enemas do not affect human colonic MUC2 and TFF3 expression. Eur J Gastroenterol Hepatol 22: 1134-1140, 2010.

72. Hamer HM, Jonkers DM, Vanhoutvin SA, Troost FJ, Rijkers G, de Bruïne A, Bast A, Venema K and Brummer RJ: Effect of butyrate enemas on inflammation and antioxidant status in the colonic mucosa of patients with ulcerative colitis in remission. Clin Nutr 29: 738-744, 2010.

73. Keszthelyi D, Troost FJ, Jonkers DM, Helyes Z, Hamer HM, Ludidi S, Vanhoutvin S, Venema K, Dekker J, Szolcsányi J, et al: Alterations in mucosal neuropeptides in patients with irritable bowel syndrome and ulcerative colitis in remission: A role in pain symptom generation? Eur J Pain 17: 1299-1306, 2013.

74. Vanhoutvin SA, Troost FJ, Hamer HM, Lindsey PJ, Koek GH, Jonkers DM, Kodde A, Venema $\mathrm{K}$ and Brummer RJ: Butyrate-induced transcriptional changes in human colonic mucosa. PLoS One 4: e6759, 2009.

75. Vanhoutvin SA, Troost FJ, Kilkens TO, Lindsey PJ, Hamer HM, Jonkers DM, Venema K and Brummer RJ: The effects of butyrate enemas on visceral perception in healthy volunteers. Neurogastroenterol Motil 21: 952-e76, 2009.

76. McRorie J, Pepple S and Rudolph C: Effects of fiber laxatives and calcium docusate on regional water content and viscosity of digesta in the large intestine of the pig. Dig Dis Sci 43: 738-745, 1998.

77. Marlett JA and Fischer MH: The active fraction of psyllium seed husk. Proc Nutr Soc 62: 207-209, 2003

78. Marlett JA, Kajs TM and Fischer MH: An unfermented gel component of psyllium seed husk promotes laxation as a lubricant in humans. Am J Clin Nutr 72: 784-789, 2000.

79. Fischer MH, Yu N, Gray GR, Ralph J, Anderson L and Marlett JA: The gel-forming polysaccharide of psyllium husk (Plantago ovata Forsk). Carbohydr Res 339: 2009-2017, 2004

80. Gibson GR, Probert HM, Loo JV, Rastall RA and Roberfroid MB: Dietary modulation of the human colonic microbiota: Updating the concept of prebiotics. Nutr Res Rev 17: 259-275, 2004

81. Gibson GR and Roberfroid MB: Dietary modulation of the human colonic microbiota: Introducing the concept of prebiotics. J Nutr 125: 1401-1412, 1995.

82. Roberfroid M: Prebiotics: The concept revisited. J Nutr 137 (Suppl 2): 830S-837S, 2007.

83. Roberfroid M, Gibson GR, Hoyles L, McCartney AL, Rastall R, Rowland I, Wolvers D, Watzl B, Szajewska H, Stahl B, et al: Prebiotic effects: Metabolic and health benefits. Br J Nutr 104 (Suppl 2): S1-S63, 2010.

84. Gibson GR, Beatty ER, Wang X and Cummings JH: Selective stimulation of bifidobacteria in the human colon by oligofructose and inulin. Gastroenterology 108: 975-982, 1995.

85. Bouhnik Y, Flourié B, Riottot M, Bisetti N, Gailing MF, Guibert A, Bornet F and Rambaud JC: Effects of fructooligosaccharides ingestion on fecal bifidobacteria and selected metabolic indexes of colon carcinogenesis in healthy humans. Nutr Cancer 26: 21-29, 1996.

86. Bouhnik Y, Raskine L, Simoneau G, Paineau D and Bornet F: The capacity of short-chain fructo-oligosaccharides to stimulate faecal bifidobacteria: A dose-response relationship study in healthy humans. Nutr J 5: 8, 2006.

87. Bouhnik Y, Vahedi K, Achour L, Attar A, Salfati J, Pochart P, Marteau P, Flourié B, Bornet F and Rambaud JC: Short-chain fructo-oligosaccharide administration dose-dependently increases fecal bifidobacteria in healthy humans. J Nutr 129: 113-116, 1999. 
88. Kleessen B, Sykura B, Zunft HJ and Blaut M: Effects of inulin and lactose on fecal microflora, microbial activity, and bowel habit in elderly constipated persons. Am J Clin Nutr 65: 1397-1402, 1997.

89.Zimmerman MA, Singh N, Martin PM, Thangaraju M, Ganapathy V, Waller JL, Shi H, Robertson KD, Munn DH and Liu K: Butyrate suppresses colonic inflammation through HDAC1dependent Fas upregulation and Fas-mediated apoptosis of T cells. Am J Physiol Gastrointest Liver Physiol 302: G1405-G1415, 2012

90. Klampfer L, Huang J, Sasazuki T, Shirasawa S and Augenlicht L: Inhibition of interferon gamma signaling by the short chain fatty acid butyrate. Mol Cancer Res 1: 855-862, 2003.

91. Stempelj M,Kedinger M, Augenlicht L and KlampferL: Essential role of the JAK/STAT1 signaling pathway in the expression of inducible nitric-oxide synthase in intestinal epithelial cells and its regulation by butyrate. J Biol Chem 282: 9797-9804, 2007.

92. May CL and Kaestner KH: Gut endocrine cell development. Mol Cell Endocrinol 323: 70-75, 2010.

93. Gunawardene AR, Corfe BM and Staton CA: Classification and functions of enteroendocrine cells of the lower gastrointestinal tract. Int J Exp Pathol 92: 219-231, 2011.

94.El-Salhy M, Ostgaard H, Gundersen D, Hatlebakk JG and Hausken T: The role of diet in the pathogenesis and management of irritable bowel syndrome (Review). Int J Mol Med 29: 723-731, 2012

95.El-Salhy M, Seim I, Chopin L, Gundersen D, Hatlebakk JG and Hausken T: Irritable bowel syndrome: The role of gut neuroendocrine peptides. Front Biosci (Elite Ed) 4: 2783-2800, 2012.

96. Tanaka-Shintani $\mathbf{M}$ and Watanabe $\mathbf{M}$ : Immunohistochemical study of enterochromaffin-like cell in human gastric mucosa Pathol Int 57: 572-583, 2007.

97.Lönroth H, Håkanson R, Lundell L and Sundler F: Histamine containing endocrine cells in the human stomach. Gut 31 : 383-388, 1990.

98. Buffa R, Capella C, Fontana P, Usellini L and Solcia E: Types of endocrine cells in the human colon and rectum. Cell Tissue Res 192: 227-240, 1978.

99. Schonhoff SE, Giel-Moloney M and Leiter AB: Minireview: Development and differentiation of gut endocrine cells Endocrinology 145: 2639-2644, 2004.

100. Sjölund K, Sandén G, Håkanson R and Sundler F: Endocrine cells in human intestine: An immunocytochemical study. Gastroenterology 85: 1120-1130, 1983.

101.Sandström O and El-Salhy M: Ageing and endocrine cells of human duodenum. Mech Ageing Dev 108: 39-48, 1999.

102.El-Salhy M: Ghrelin in gastrointestinal diseases and disorders: A possible role in the pathophysiology and clinical implications (Review). Int J Mol Med 24: 727-732, 2009.

103. Tolhurst G, Reimann F and Gribble FM: Intestinal sensing of nutrients. Handb Exp Pharmacol 209: 309-335, 2012.

104.Lee J, Cummings BP, Martin E, Sharp JW, Graham JL, Stanhope KL, Havel PJ and Raybould HE: Glucose sensing by gut endocrine cells and activation of the vagal afferent pathway is impaired in a rodent model of type 2 diabetes mellitus. Am J Physiol Regul Integr Comp Physiol 302: R657-R666, 2012.

105. Parker HE, Reimann F and Gribble FM: Molecular mechanisms underlying nutrient-stimulated incretin secretion. Expert Rev Mol Med 12: e1, 2010.

106. Raybould HE: Nutrient sensing in the gastrointestinal tract: Possible role for nutrient transporters. J Physiol Biochem 64 349-356, 2008.

107. San Gabriel A, Nakamura E, Uneyama H and Torii K: Taste, visceral information and exocrine reflexes with glutamate through umami receptors. J Med Invest 56 (Suppl): 209-217, 2009.

108. Rudholm T, Wallin B, Theodorsson E, Näslund E and Hellström PM: Release of regulatory gut peptides somatostatin, neurotensin and vasoactive intestinal peptide by acid and hyperosmolal solutions in the intestine in conscious rats. Regul Pept 152 $8-12,2009$

109. Sternini C, Anselmi L and Rozengurt E: Enteroendocrine cells: A site of 'taste' in gastrointestinal chemosensing. Curr Opin Endocrinol Diabetes Obes 15: 73-78, 2008.

110. Sternini C: Taste receptors in the gastrointestinal tract IV. Functional implications of bitter taste receptors in gastrointestinal chemosensing. Am J Physiol Gastrointest Liver Physiol 292: G457-G461, 2007.

111. Buchan AM: Nutrient Tasting and Signaling Mechanisms in the Gut III. Endocrine cell recognition of luminal nutrients. Am J Physiol 277: G1103-G1107, 1999.
112. Montero-Hadjadje M, Elias S, Chevalier L, Benard M, Tanguy Y, Turquier V, Galas L, Yon L, Malagon MM, Driouich A, et al: Chromogranin A promotes peptide hormone sorting to mobile granules in constitutively and regulated secreting cells: Role of conserved N-and C-terminal peptides. J Biol Chem 284: 12420-12431, 2009.

113. Shooshtarizadeh P, Zhang D, Chich JF, Gasnier C, Schneider F, Haïkel Y, Aunis D and Metz-Boutigue MH: The antimicrobial peptides derived from chromogranin/secretogranin family, new actors of innate immunity. Regul Pept 165: 102-110, 2010.

114. El-Salhy M, Gundersen D, Gilja OH, Hatlebakk JG and Hausken T: Is irritable bowel syndrome an organic disorder? World J Gastroenterol 20: 384-400, 2014.

115. El-Salhy M, Hatlebakk JG, Gilja OH and Hausken T: Irritable bowel syndrome: Recent developments in diagnosis, pathophysiology, and treatment. Expert Rev Gastroenterol Hepatol 8: 435-443, 2014.

116. Rindi G, Inzani F and Solcia E: Pathology of gastrointestinal disorders. Endocrinol Metab Clin North Am 39: 713-727, 2010.

117. Seim I, El-Salhy M, Hausken T, Gundersen D and Chopin L: Ghrelin and the brain-gut axis as a pharmacological target for appetite control. Curr Pharm Des 18: 768-775, 2012.

118. Gershon MD: 5-Hydroxytryptamine (serotonin) in the gastrointestinal tract. Curr Opin Endocrinol Diabetes Obes 20: 14-21, 2013.

119. Holzer P and Farzi A: Neuropeptides and the microbiota-gutbrain axis. Adv Exp Med Biol 817: 195-219, 2014.

120. Cani PD, Everard A and Duparc T: Gut microbiota, enteroendocrine functions and metabolism. Curr Opin Pharmacol 13: 935-940, 2013

121. Everard A and Cani PD: Gut microbiota and GLP-1. Rev Endocr Metab Disord 15: 189-196, 2014

122. Arora T, Loo RL, Anastasovska J, Gibson GR, Tuohy KM, Sharma RK, Swann JR, Deaville ER, Sleeth ML, Thomas EL, et al: Differential effects of two fermentable carbohydrates on central appetite regulation and body composition. PLoS One 7: e43263, 2012.

123. Maljaars PW, Keszthelyi D and Masclee AA: An ileal brakethrough? Am J Clin Nutr 92: 467-468, 2010.

124. Van Citters GW and Lin HC: Ileal brake: Neuropeptidergic control of intestinal transit. Curr Gastroenterol Rep 8: 367-373, 2006.

125. Lin HC, Zhao XT, Wang L and Wong H: Fat-induced ileal brake in the dog depends on peptide YY. Gastroenterology 110: 1491-1495, 1996.

126. Pironi L, Stanghellini V, Miglioli M, Corinaldesi R, De Giorgio R, Ruggeri E, Tosetti C, Poggioli G, Morselli Labate AM, Monetti N, et al: Fat-induced ileal brake in humans: A dose-dependent phenomenon correlated to the plasma levels of peptide YY. Gastroenterology 105: 733-739, 1993.

127. Spiller RC, Trotman IF, Adrian TE, Bloom SR, Misiewicz JJ and Silk DB: Further characterisation of the 'ileal brake' reflex in man - effect of ileal infusion of partial digests of fat, protein, and starch on jejunal motility and release of neurotensin, enteroglucagon, and peptide YY. Gut 29: 1042-1051, 1988.

128. Spiller RC, Trotman IF, Higgins BE, Ghatei MA, Grimble GK, Lee YC, Bloom SR, Misiewicz JJ and Silk DB: The ileal brake - inhibition of jejunal motility after ileal fat perfusion in man. Gut 25: 365-374, 1984.

129. Goumain M, Voisin T, Lorinet AM, Ducroc R, Tsocas A, Rozé C, Rouet-Benzineb P, Herzog H, Balasubramaniam A and Laburthe M: The peptide YY-preferring receptor mediating inhibition of small intestinal secretion is a peripheral $\mathrm{Y}(2)$ receptor: Pharmacological evidence and molecular cloning. Mol Pharmacol 60: 124-134, 2001.

130. Souli A, Chariot J, Voisin T, Presset O, Tsocas A, Balasubramaniam A, Laburthe M and Rozé C: Several receptors mediate the antisecretory effect of peptide YY, neuropeptide Y, and pancreatic polypeptide on VIP-induced fluid secretion in the rat jejunum in vivo. Peptides 18: 551-557, 1997.

131. Whang EE, Hines OJ, Reeve JR Jr, Grandt D, Moser JA, Bilchik AJ, Zinner MJ, McFadden DW and Ashley SW: Antisecretory mechanisms of peptide YY in rat distal colon. Dig Dis Sci 42: 1121-1127, 1997.

132. Mazzawi T and El-Salhy M: Changes in small intestinal chromogranin A-immunoreactive cell densities in patients with irritable bowel syndrome after receiving dietary guidance. Int J Mol Med 37: 1247-1253, 2016. 
133. Mazzawi T, Gundersen D, Hausken T and El-Salhy M: Increased gastric chromogranin A cell density following changes to diets of patients with irritable bowel syndrome. Mol Med Rep 10: 2322-2326, 2014

134. Mazzawi T, Gundersen D, Hausken T and El-Salhy M: Increased chromogranin A cell density in the large intestine of patients with irritable bowel syndrome after receiving dietary guidance. Gastroenterol Res Pract 2015: 823897, 2015.

135. Mazzawi T, Hausken T, Gundersen D and El-Salhy M: Effect of dietary management on the gastric endocrine cells in patients with irritable bowel syndrome. Eur J Clin Nutr 69: 519-524, 2015.

136. Mazzawi T and El-Salhy M: Changes in duodenal enteroendocrine cells in patients with irritable bowel syndrome following dietary guidance. Exp Biol Med: 0: 1-8, 2017. DOI $10.1177 / 1535370217699537$.

137. Mazzawi T, Hausken T, Gundersen D and El-Salhy M: Dietary guidance normalizes large intestinal endocrine cell densities in patients with irritable bowel syndrome. Eur J Clin Nutr 70 $175-181,2016$.

138. Mazzawi T and El-Salhy M: Dietary guidance and ileal enteroendocrine cells in patients with irritable bowel syndrome. Exp Ther Med 12: 1398-1404, 2016.

139. Soret R, Chevalier J, De Coppet P, Poupeau G, Derkinderen P, Segain JP and Neunlist M: Short-chain fatty acids regulate the enteric neurons and control gastrointestinal motility in rats. Gastroenterology 138: 1772-1782, 2010.

140. Bellini M, Gambaccini D, Salvadori S, Tosetti C, Urbano MT, Costa F, Monicelli P, Mumolo MG, Ricchiuti A, De Bortoli N, et al: Management of chronic constipation in general practice. Tech Coloproctol 18: 543-549, 2014.

141. Furnari M, de Bortoli N, Martinucci I, Bodini G, Revelli M, Marabotto E, Moscatelli A, Del Nero L, Savarino E, Giannini EG, et al: Optimal management of constipation associated with irritable bowel syndrome. Ther Clin Risk Manag 11: 691-703, 2015.

142. Alaimo K, McDowell MA, Briefel RR, Bischof AM, Caughman CR, Loria CM and Johnson CL: Dietary intake of vitamins, minerals, and fiber of persons ages 2 months and over in the United States: Third National Health and Nutrition Examination Survey, Phase 1, 1988-91. Adv Data 258: 1-28, 1994.
143. Briefel RR, Sempos CT, McDowell MA, Chien S and Alaimo K: Dietary methods research in the third National Health and Nutrition Examination Survey: Underreporting of energy intake. Am J Clin Nutr 65 (Suppl 4): 1203S-1209S, 1997.

144. McRorie JW Jr: Evidence-based approach to fiber supplements and clinically meaningful health benefits, Part 2: What to look for and how to recommend an effective fiber therapy. Nutr Today 50: 90-97, 2015

145. McRorie JW Jr: Evidence-based approach to fiber supplements and clinically meaningful health benefits, Part 1: What to look for and how to recommend an effective fiber therapy. Nutr Today 50: 82-89, 2015.

146. Rutten JM, Korterink JJ, Venmans LM, Benninga MA and Tabbers MM: Nonpharmacologic treatment of functional abdominal pain disorders: A systematic review. Pediatrics 135: 522-535, 2015.

147. Shah SL and Lacy BE: Dietary interventions and irritable bowel dyndrome: A review of the evidence. Curr Gastroenterol Rep 18 41, 2016.

148. Ansari R, Attari F, Razjouyan H, Etemadi A, Amjadi H, Merat S and Malekzadeh R: Ulcerative colitis and irritable bowe syndrome: Relationships with quality of life. Eur J Gastroenterol Hepatol 20: 46-50, 2008

149. Ford AC, Chey WD, Talley NJ, Malhotra A, Spiegel BM and Moayyedi P: Yield of diagnostic tests for celiac disease in individuals with symptoms suggestive of irritable bowel syndrome: Systematic review and meta-analysis. Arch Intern Med 169 651-658, 2009

150. Brandt LJ, Prather CM, Quigley EM, Schiller LR, Schoenfeld P and Talley NJ: Systematic review on the management of chronic constipation in North America. Am J Gastroenterol 100 (Suppl 1) S5-S21, 2005. 